\title{
Sistem Anggaran Berbasis Kinerja pada APBN di Indonesia Perspektif Ekonomi Islam
}

\author{
Aan Jaelani \\ Fakultas Syari'ah \& Ekonomi Islam IAIN Syekh Nurjati Cirebon \\ Email: iainanjal@gmail.com
}

\begin{abstract}
Abstrak
Artikel ini mengkaji anggaran negara dengan sistem keuangan berbasis kinerja di Indonesia, yang sebelumnya menerapkan sistem keuangan berimbang. Dengan menggunakan metode kualitatif dan pendekatan content analysis dalam memahami teori dan dokumen sistem keuangan di Indonesia. Tulisan ini menyimpulkan bahwa sistem keuangan berbasis kinerja di Indonesia memberikan arah baru dalam pengelolaan keuangan yang lebih transparan dan akuntabel untuk kegiatan pembangunan dalam mewujudkan kesejahteraan masyarakat.
\end{abstract}

Kata Kunci: reformasi anggaran, keuangan berbasis kinerja, APBN, ekonomi Islam

\begin{abstract}
This article reviews the state budget with a performance-based financial system in Indonesia, which previously implemented a balanced financial system. By using qualitative method and content analysis approach in understanding the theory and document of the financial system in Indonesia. This paper concludes that performance-based financial system in Indonesia provides a new direction in more transparent and accountable financial management for development activities in realizing community welfare.
\end{abstract}

Keywords: budgetary reform, performance-based finance, APBN, Islamic economy

\section{Pendahuluan}

Peran negara dalam ekonomi Islam dilakukan dalam rangka melanjutkan misi kenabian, ${ }^{1}$ yaitu pencapaian al-maqashid alsyari'ah (tujuan-tujuan syari'ah). ${ }^{2}$ Negara sebagai agen Tuhan untuk merealisasikan almaqashid al-Syari'ah. Sebagai contoh, pada negara Islam pengalokasian sumber-sumber daya yang tidak sesuai dengan tujuan syara' tidak dibenarkan. Karena itu, penerimaan keadilan dan persamaan menjadi komponen esensial dalam kebijakan publik (public policy). Jadi, kemaslahatan yang mengacu

1 Al-Mawardi, Adab al-Dunya waal-Din (Beirut: Dar al-Fikr, 1995), 94.

${ }^{2}$ Baca Abu Ishaq al-Syathibi, al-Muwafaqat fi Ushul al-Syari' ah (Cairo: al-Maktabah al-Tijaniyah al-Kubra, 1975), vol. 2, 6-7. pada pemenuhan kebutuhan masyarakat menjadi kata kunci. ${ }^{3}$

Agenda utama dari era reformasi untuk mempercepat pembangunan daerah adalah otonomi daerah dan demokratisasi ekonomi. Tema sentral dari kebijaksanaan pembangunan dalam era reformasi adalah mengedepankan paradigma pembangunan manusia yang menempatkan rakyat sebagai pelaku pembangunan dan menempatkan ekonomi daerah sebagai wahana mewujudkan kesejahteraan masyarakat.

Kebijakan pemerintah yang dituangkan dalam bentuk APBN justru berlawanan arah dengan peran pemerintah yang semestinya mewujudkan kesejahteraan bagi masyarakat. Fenomena politik anggaran

3 Aan Jaelani, Masyarakat Islam dalam Pandangan al-Mawardi (Bandung: Pustaka Setia, 2006), 116. 
dalam pengelolaan APBN di kalangan DPR yang memiliki wewenang untuk melakukan perubahan anggaran lebih menyebabkan terjadinya korupsi baik secara pribadi maupun kelompok.

Oleh karena masyarakat sendiri tidak akan mampu mengentaskan kemiskinan ekonomi dan sosial, maka untuk memberdayakan masyarakat, terutama masyarakat yang miskin diperlukan pemberdayaan awal (self empowerment) dari pihak luar terutama dari pemerintah. Bahkan, menurut Sri-Edi Swasono, ${ }^{4}$ rakyat telah mengalami proses pemiskinan (impoverishment) dan pelumpuhan (disempowerment), yang terjadi seiring dengan pembangunan nasional yang mengabaikan orientasi kerakyatan.

Perkembangan yang ada cenderung menampakkan kompleksitas dan penyimpangan-penyimpangan etika dalam kegiatan ekonomi. ${ }^{5}$ Ibnu Taimiyah dalam hal ini, memandang perlu keterlibatan negara dalam aktifitas ekonomi dalam rangka melindungi hak-hak masyarakat dari ancaman kezaliman para pelaku bisnis yang ada, dan untuk kepentingan manfaat yang lebih besar. Dalam kaitan ini, menurut Jaelani, ${ }^{6}$ intervensi negara dalam kegiatan ekonomi bertujuan menghapuskan kemiskinan sebagai kewajiban negara. Bagi Ibnu Taimiyah, ${ }^{7}$ seseorang harus hidup sejahtera dan tidak tergantung pada orang lain, sehingga mereka bisa memenuhi sejumlah kewajibannya.

Pengurangan kemiskinan menjadi sebuah agenda penting kebijakan pembangunan di

\footnotetext{
${ }^{4}$ Sri-Edi Swasono, Restrukturisasi, Keadilan Sosial dan Gobalisasi, Ceramah pada Program Pascasarjana Universitas Airlangga, Batam 29 Maret 2001.

${ }^{5}$ Muh. al-Assal dan Fathi Abd. Karim, Hukum Ekonomi Islam (Jakarta:Pustaka Firdaus, 1999), 101-102. Lihat pula Sri-Edi Swasono, Mewaspadai Pasar Bebas (dalam Dari Lengser ke Lengser), Jakarta: Penerbit Universitas Indonesia, 2001.

6 Aan Jaelani, Keuangan Publik: Analisis Sejarah Pemikiran Ekonomi Islam (Cirebon: CV. Aksarasatu, 2018), 167.

${ }^{7}$ Ibn Taymiyah, al-Hisbah fi al-Islam (Beirut: Dar al-Kutub al-'Arabiyah, 1994), 20-22.
}

Indonesia selama ini. Angka statistik kemiskinan mengalami penurunan dari tahun ke tahun, tetapi tampaknya agenda pengurangan kemiskinan menjadi sebuah proyek besar yang tidak pernah akan selesai. Di masa lalu pengurangan kemiskinan menggunakan pendekatan yang terpusat, top down, mobilisasi, seragam dan berbasis proyek yang bersifat off budget.

Pada masa reformasi pendekatan pengurangan kemiskinan telah mengalami pergeseran ke arah yang lebih desentralistik, bottom up dan partisipatif, yang semua itu semakin canggih dikemas, menyusul lahirnya komitmen internasional dalam Millenium Development Goals (MDGs). Kini muncul sebuah konsep yang lebih bertenaga berupa anggaran pro rakyat miskin (pro poor budget), yang lahir bersamaan dengan konsep-konsep lain seperti anggaran alternatif, anggaran rakyat, anggaran partisipatif (participatory budgeting) maupun anggaran yang responsif gender (gender budgeting). Didorong oleh lahirnya konsepkonsep baru itu, skema pendanaan pengurangan kemiskinan tidak lagi off budget, tetapi ia harus menyatu (integrasi) ke dalam (built in) sistem perencanaan dan penganggaran. Dengan kata lain, pendekatan baru itu mengharuskan pengarusutamaan kemiskinan (poverty mainstreaming) dalam perencanaan dan pengganggaran.

Di Indonesia, kesepakatan MDGs diteruskan dengan komitmen pengarus-utamaan kemiskinan dan gender dalam perencanaan dan pengganggaran APBN/APBD sejak 2003/2004. Melalui Rencana Pembangunan Jangka Menengah Nasional (RPJMN) 2004-2009 pemerintah berupaya (2004-2009) diharapkan dapat menurunkan persentase penduduk miskinmenjadi 8,2 persen pada tahun 2009. Pada saat yang sama pemerintah juga telah mengeluarkan Strategi Nasional Penanggulangan Kemiskinan (SNPK) yang disusun melalui proses partisipatif dengan melibatkan seluruh stakeholders pembangunan di Indonesia. SNPK mengedepankan pendekatan berbasis hak (rightbased approach) sebagai pendekatan utama dengan menegaskan pencapaian secara bertahap dan progresif (progressive realization) dalam penghormatan (respect), perlindungan (protect) dan pemenuhan (fulfill) hak dasar rakyat, memberikan perhatian terhadap perwujudan kesetaraan dan keadilan gender, serta percepatan pengembangan wilayah.

Sedangkan dalam konteks pengelolaan APBN, pengeluaran pemerintah 
yang terdapat dalam Anggaran Pendapatan Belanja Negara (APBN) merupakan salah satu alat kebijakan fiskal pemerintah. Pemerintah dapat menggunakannya untuk mengelola perekonomian negara. ${ }^{8}$ APBN pada perkembangannya telah mengalami banyak perubahan struktur. APBN saat ini menggunakan sistem anggaran berbasis kinerja berdasarkan UU Nomor 1 tahun 2004.

Sejak tahun 1969 diterapkan sistem berimbang dan dinamis dalam penyusunan Anggaran Pendapatan Belanja Negara. Sistem anggaran berimbang dan dinamis ini menggantikan sistem anggaran sebelumnya pada masa orde lama yang belum membedakan antara anggran belanja dengan penerimaan. Pembedaan antara anggaran belanja dengan penerimaan akan mempermudah mengetahui berapa besar anggaran belanja pemerintah untuk sektor publik. Namun demikian, pengelolaan anggaran yang semakin efektif tersebut kurang berpihak pada tujuan pencapaian kesejahteraan masyarakat.

Karena itu penting dilakukan penelusuran tentang peluang-peluang hadirnya reformasi kebijakan anggaran yang mengarah pada pro poor budget yang secara substansial mengandung tujuan-tujuan pengurangan kemiskinan dan promosi kesejahteraan, dan tentunya mengurangi terjadinya penyimpangan anggaran. Hal yang dapat diasumsikan bahwa desain institusional itu penting tetapi tidak cukup untuk melahirkan APBN yang pro poor secara konkret.

Kinerja pemerintah dalam upaya penyediaan pelayanan dasar (pendidikan dan kesehatan) serta penanggulangan kemiskinan masih menghadapi tantangan efektifitas dan kesinambungannya karena dampak APBN dalam mengentaskan kemiskinan ternyata berbiaya tinggi dan fluktuatif. Peningkatan alokasi anggaran pada kenyataannya baru membuat ongkos untuk menurunkan kemiskinan di Indonesia semakin mahal (bila tidak ingin disebut boros).

8 Aan Jaelani, Fiscal Policy in Indonesia: Analysis of State Budget 2017 in Islamic Economic Perspective. International Journal of Economics and Financial Issues, 2017: 7 (5): 14-24.
APBN merupakan persoalan pertaruhan kekuasaan dan kepentingan yang beragam. APBN menjadi arena kontestasi beragam aktor politik di tingkat pusat yang masing-masing mempunyai kepentingan secara beragam pula. Politik anggaran yang berorientasi pada pengurangan kemiskinan (pro poor) dan berpihak kepada kesejahteraan tidak mungkin turun dari langit, tetapi selalu diawali dengan kontestasi politik yang dimenangkan oleh koalisi pro poor atas kekuatan pro elite.

Karena itu, persoalan-persoalan yang selalu muncul dalam pengelolaan keuangan negara antara lain terkait regulasi nasional tentang pengelolaan keuangan negara melalui APBN, pengelolaan APBN dalam konstalasi politik anggaran dan tinjauan ekonomi Islam,prinsip-prinsip pengelolaan APBN yang menciptakan pro poor budgeting atau pro elite budgeting, faktor-faktor penyebab terjadinya penyimpangan anggaran dan korupsi dalam pemerintahan dan upaya-upaya pencegahannya, serta nilai strategis pengelolaan APBN dari sisi politik anggaran dan pembangunan di Indonesia.

Artikel ini bertujuan untuk menjelaskan permasalahan-permasalahan yang terkait dengan manajemen APBN dalam sistem anggaran berbasis kinerja di Indonesia dalam perspektif ekonomi Islam. Hal ini diharapkan sebagai ikhtiar secara teoritis untuk mengembangkan konsep dan teori ekonomi Islam dalam pengelolaan anggaran pemerintah.

\section{Pembahasan \\ Literature Review}

Studi tentang pengelolaan anggaran terkait dengan keuangan negara dalam bentuk penerimaan dan pengeluaran pemerintah. Karena itu, studi ini terkait dengan disiplin keuangan publik atau keuangan negara yang menekankan peran pemerintah dalam pengelolaan anggaran untuk kesejahteraan masyarakat. Beberapa studi literatur tentang peran dalam pengelolaan anggaran untuk kesejahteraan rakyat antara lain Paul A. Samuelson ${ }^{9}$ dalam Economics. Karya ini menjadi buku penting dalam kajian ilmu ekonomi yang membawa

${ }^{9}$ Paul A. Samuelson, Economics (New York: McGraw-Hill Book Company, 2008). 
tradisi liberalisme dan pasar bebas sebagai karakter dari globalisasi ekonomi.

Robin W. Boadway and Neil Bruce ${ }^{10}$ melakukan studi tentang tema ini dalam Welfare Economics. Buku ini memberikan penjelasan tentang paradigma kesejahteraan ekonomi dalam perspektif kapitalisme. Alessandro Roncaglia ${ }^{11}$ dalam The Wealth of Ideas: a History of Economic Thought memberikan penjelasan dengan analisis ekonomi tentang perkembangan pemikiran ekonomi klasik sampai neoliberalisme.

Tulisan lain tentang hubungan negara dan pasar dapat dibaca Murray N. Rothbard ${ }^{12}$ dalam Power and Market Government and the Economy. Buku ini penting untuk melihat dimensi peran dan pergulatan kekuatan pemerintah dan pasar dalam ekonomi. I. Wallerstein $^{13}$ dalam The Capitalist WorldEconomy mengungkapkan secara panjang sejarah kapitalisme dan globalisasi yang bergerak secara cepat di dunia modern.

Shinichi Ichimura, et. al (eds.) ${ }^{14}$ dalam Transition from Socialist to Market Economies: Comparison of European and Asian Experience menggambarkan pula kemenangan kapitalisme atas sosialisme. Sedangkan kritik atas globalisasi dan pasar bebas antara lain karya Sri-Edi Swasono, ${ }^{15}$ Ekspose Ekonomika: Mewaspadai Globalisasi dan Pasar Bebas, Yogyakarta: Pustep UGM, 2010 dan Mewaspadai Pasar Bebas (dalam Dari Lengser ke Lengser). Tokoh ekonomi rakyat ini banyak

10 Robin W. Boadway and Neil Bruce, Welfare Economics (Oxford: Basil Blackwell, 1984).

11 Alessandro Roncaglia, The Wealth of Ideas: a History of Economic Thought (New York: Cambridge University Press, 2006).

${ }_{12}$ Murray N. Rothbard, Power and Market Government and the Economy (Kansas: Institute for Humane Studies, Inc., 1977).

13 I. Wallerstein, The Capitalist WorldEconomy (New York: Cambridge University Press, 1979)

${ }^{14}$ Shinichi Ichimura, et al (eds.), Transition from Socialist to Market Economies: Comparison of European and Asian Experience (New York; Palgrave Macmillan, 2009

15 Sri-Edi Swasono, Ekspose Ekonomika: Mewaspadai Globalisasi dan Pasar Bebas, Yogyakarta: Pustep UGM, 2010. menghasilkan karya yang mengkritik globalisasi, pasar bebas, neoliberalime dan fokus pada memperjuangkan demokrasi ekonomi berbasis Pancasila. Rainer Adam, dkk. ${ }^{16}$ dalam Persaingan dan Ekonomi Pasar di Indonesia memaparkan kondisi ekonomi Indonesia di tengah arus pasar bebas.

Tokoh lain adalah Mubyarto ${ }^{17}$ yang menulis Reformasi Sistem Ekonomi Dari Kapitalisme Menuju Ekonomi Kerakyatan. Karya ini cukup penting bukan hanya upaya akademik penulis dalam mengkritik kapitalisme melainkan juga bentuk perjuangan dalam mengimplementasikan ekonomi kerakyatan. Kemudian Indra Ismawan $^{18}$ dalam Sukses di Era Ekonomi Liberal Bagi Koperasi dan Perusahaan Kecil-Menengah. Buku ini memaparkan kiatkiat koperasi dan perusahaan kecil-menengah dalam menghadapi era ekonomi liberal. Mahmud Thoha, et al, ${ }^{19}$ dalam Globalisasi Krisis Ekonomi dan Kebangkitan Ekonomi Kerakyatan memberikan analisis krisis ekonomi di Indonesia akibat globalisasi dan memberikan alternatif bagi pengembangan ekonomi kerakyatan.

Studi lain dari Jamzy Zodik ${ }^{20}$ meneliti hubungan pengeluaran pemerintah dan pertumbuhan ekonomi regional. Penelitian ini cukup baik menganalisis pengeluaran pemerintah Indonesia yang berpengaruh terhadap pertumbuhan ekonomi regional. Namun, fakta lain tentang korupsi nampaknya tidak diungkapkan. Anton

\footnotetext{
${ }^{16}$ Rainer Adam, et al, Persaingan dan Ekonomi Pasar di Indonesia (Jakarta: Friedrich Nauman Stiftung-Indonesia, 2004), 43.

${ }^{17}$ Mubyarto, Reformasi Sistem Ekonomi Dari Kapitalisme Menuju Ekonomi Kerakyatan (Yogyakarta: Aditya Media, 1999).

18 Indra Ismawan, Sukses di Era Ekonomi Liberal Bagi Koperasi dan Perusahaan KecilMenengah (Jakarta: Gramedia, 2001).

${ }^{19}$ Mahmud Thoha, et al, Globalisasi Krisis Ekonomi dan Kebangkitan Ekonomi Kerakyatan (Jakarta: Pustaka Quantum, 2002).

20 Jamroni Sodik,'Pengeluaran Pemerintah dan Pertumbuhan Ekonomi Regional: Studi Kasus Data Panel di Indonesia". Jurnal Ekonomi Pembangunan, Vol. 12 , No. 1, Universitas Islam Indonesia, 2007.
} 
Hermanto Gunawan ${ }^{21}$ dalam Anggaran Pemerintah dan Inflasi di Indonesia memberikan penjelasan tentang hubungan anggaran pemerintah dan inflasi di Indonesia. Buku ini sangat relevan untuk mengungkap pola dan sistem pengelolaan APBN di Indonesia, namun hanya menganalisis kondisi ekonomi Indonesia pada masa Orde Baru.

Ani Sri Rahayu ${ }^{22}$ dalam Pengantar Kebijakan Fiskal memberikan gambaran tentang kebijakan fiskal yang terkait dengan perpajakan dan pengeluaran pemerintah Indonesia. Buku ini cukup baik menjelaskan struktur APBN dan pengelolaannya sejak masa reformasi, meskipun tidak banyak mengungkap persoalan-persoalan di bidang anggaran.

Tim Pengkajian SPKN BPKN $^{23}$ dalam Upaya Pencegahan dan Penanggulangan Korupsi pada Pengelolaan $A P B N / A P B D$ menjelaskan secara legal dan institusional berbagai praktek korupsi dan upaya pemberantasannya dalam sistem pemerintahan di Indonesia. Namun demikian, buku ini sangat sederhana dalam mengungkap politik anggaran dan penyimpangannya.

Sedangkan kajian anggaran pemerintah sebagai bagian dari keuangan publik dalam ekonomi Islam dapat ditelusuri antara lain Yasin Ghadi dalam al-Amwal wa al-Amlak al-'Ammah fi al-Islam wa Hukm al-I'tida' 'Alaiha ${ }^{24}$ memberikan analisis hukum Islam tentang keuangan negara (almal al-'am) yang dihubungkan dengan konsep harta dan pengelolaannya berdasarkan kaidah-kaidah syari'ah. Namun, karya ini kurang banyak mengungkap

21 Anton Hermanto Gunawan, Anggaran Pemerintah dan Inflasi di Indonesia (Jakarta: Gramedia Pustaka Utama, 1991)

${ }^{22}$ Ani Sri Rahayu, Pengantar Kebijakan Fiskal (Jakarta: Bumi Aksara, 2010).

${ }^{23}$ Tim Pengkajian SPKN BPKN, Upaya Pencegahan dan Penanggulangan Korupsi pada Pengelolaan APBN/APBD (Jakarta: BPKP, 2002).

${ }^{24}$ Yasin Ghadi, al-Amwal wa al-Amlak al'Ammah fi al-Islam wa Hukm al-I'tida' 'Alaiha (Mu'tah: Mu'assasah Ram, 1994). dimensi pengelolaan keuangan publik dan penerapannya melalui suatu politik anggaran.

Mahmud Julaid dalam Qira'at fi alMaliyat al-'Ammah fi al-Islam ${ }^{25}$ melakukan analisis terhadap konsep keuangan publik (al-maliyat al-'ammah) dan penerapannya dalam pemerintahan Islam pada masa klasik, namun relevansi pengelolaan keuangan negara dalam konteks pemerintahan sekarang ini tidak cukup memberi penjelasan yang lengkap.

M. Nejatullah Siddiqi melalui karyanya, Teaching Public Finance in Islamic Perspective, ${ }^{26}$ menjelaskan secara komprehensif tentang keuangan publik Islam dan penerapannya dalam konteks ekonomi modern di negara-negara Muslim. Namun, karena karya ini lebih bercorak "modul" sebagai bahan kuliah, sehingga tidak ditemukan analisis mendalam tentang "diskusi" pengelolaan anggaran dari para pemikir ekonomi Islam.

Kajian penting keuangan publik dalam Islam dapat ditemukan pula pada karya Zafar Iqbal, an Islamic Perspective on Public Finance. ${ }^{27}$ Karya ini mengungkap keuangan publik yang membahas secara komprehensif teori keadilan dalam ekonomi, teori pajak, teori anggaran, organisasi komersial sektor keuangan publik, dan korupsi. Meskipun karya ini membandingkan teori-teori tersebut perspektif Islam dan Barat, namun kurang memberikan analisis politik ekonomi Islam.

\section{Metodologi}

Dalam bahasan tentang sistem keuangan berbasis kinerja, persoalan dibahas dengan metode kualitatif dan pendekatan content analysis. Langkah-langkah yang dilakukan adalah pengumpulan data berupa dokumen tentang keuangan berbasis kinerja,

${ }^{25}$ Mahmud Julaid, Qira'at fi al-Maliyat al'Ammah fi al-Islam (Jeddah: IDB-IRTI, 1995/1415).

26 M. Nejatullah Siddiqi, Teaching Public Finance in Islamic Perspective (Jeddah: Centre for Research in Islamic Economics King Abdul Aziz University, 1413/1992).

27 Zafar Iqbal, an Islamic Perspective on Public Finance (Australia: University of South Australia, 2003). 
melakukan verifikasi dokumen yang sesuai dengan masalah yang ada, menganalisis dokumen dengan teori yang tepat, dan membuat kesimpulan.

\section{Hasil dan Pembahasan \\ 1. Pengertian dan Struktur APBN ${ }^{28}$}

Anggaran Pendapatan dan Belanja Negara (APBN) adalah rencana keuangan tahunan pemerintahan negara yang disetujui oleh Dewan Perwakilan Rakyat. (Pasal 1 angka 7, UU No. 17/2003). Merujuk Pasal 12 UU No. 1/2004 tentang Perbendaharaan Negara, APBN dalam satu tahun anggaran meliputi:

a. Hak pemerintah pusat yang diakui sebagai penambah nilai kekayaan bersih;

b. Kewajiban pemerintah pusat yang diakui sebagai pengurang nilai kekayaan bersih;

c. Penerimaan yang perlu dibayar kembali dan atau pengeluaran yang akan diterima kembali, baik pada tahun anggaran yang bersangkutan maupun pada tahun-tahun anggaran berikutnya.

Semua penerimaan dan pengeluaran negara dilakukan melalui rekening kas umum negara (Pasal 12 ayat (2) UU No. 1/2004). Tahun anggaran adalah periode pelaksanaan APBN selama 12 bulan.

Sejak tahun 2000, Indonesia menggunakan tahun kalender sebagai tahun anggaran, yaitu dari tanggal 1 Januari sampai dengan tanggal 31 Desember. Sebelumnya, tahun anggaran dimulai tanggal 1 April sampai dengan 31 Maret tahun berikutnya. Penggunaan tahun kalender sebagai tahun anggaran ini kemudian dikukuhkan dalam UU Keuangan Negara dan UU

28 Bagian ini bersumber pada makalah Suminto, "Pengelolaan APBN dalam Sistem Manajemen Keuangan Negara”. Makalah ini sebagai bahan penyusunan Budget In Brief 2004 pada Ditjen Anggaran, Departemen Keuangan. Lihat pula UU RI Nomor 17 Tahun 2003 tentang Keuangan Negara, UU RI Nomor 1 Tahun 2004 tentang Perbendaharaan Negara.
Perbendaharaan Negara (Pasal 4 UU No. 17/2003 dan Pasal 11 UU No. 1/2004).

Sebagaimana ditegaskan dalam Bagian Penjelasan UU No. 17/2003, anggaran adalah alat akuntabilitas, manajemen, dan kebijakan ekonomi. Sebagai fungsi akuntabilitas, pengeluaran anggaran hendaknya dapat dipertanggungjawabkan dengan menunjukkan hasil (result) berupa outcome atau setidaknya output dari dibelanjakannya dana-dana publik tersebut. Sebagai alat manajemen, sistem penganggaran selayaknya dapat membantu aktivitas berkelanjutan untuk memperbaiki efektifitas dan efisiensi program pemerintah. Sedangkan sebagai instrumen kebijakan ekonomi, anggaran berfungsi untuk mewujudkan pertumbuhan dan stabilitas perekonomian serta pemerataan pendapatan dalam rangka mencapai tujuan bernegara.

Merujuk Pasal 3 Ayat (4) UU No. 17/2003, APBN mempunyai fungsi otorisasi, perencanaan, pengawasan, alokasi, distribusi dan stabilisasi. Fungsi otorisasi mengandung arti bahwa anggaran negara menjadi dasar untuk melaksanakan pendapatan dan belanja pada tahun yang bersangkutan. Fungsi perencanaan mengandung arti bahwa anggaran negara menjadi pedoman bagi manajemen dalam merencanakan kegiatan pada tahun yang bersangkutan. Fungsi pengawasan mengandung arti bahwa anggaran negara menjadi pedoman untuk menilai apakah kegiatan penyelenggaraan negara sesuai dengan ketentuan yang telah ditetapkan. Fungsi alokasi mengandung arti bahwa anggaran negara harus diarahkan untuk mengurangi pengangguran dan pemborosan sumber daya, serta meningkatkan efisiensi dan efektifitas perekonomian. Fungsi distribusi mengandung arti bahwa kebijakan anggaran negara harus memperhatikan rasa keadilan dan kepatutan. Fungsi stabilisasi mengandung arti bahwa anggaran pemerintah menjadi alat untuk memelihara dan mengupayakan keseimbangan fundamental perekonomian. 


\section{Reformasi APBN}

Undang-undang RI Nomor 17 Tahun 2003 tentang keuangan negara mereformasi secara signifikan sistem penganggaran yang telah puluhan tahun diterapkan di Indonesia. Secara singkat, faktor-faktor yang mendorong reformasi di bidang penganggaran ini adalah: ${ }^{29}$ ada beberapa aspek dari proses penganggaran di Indonesia yang menghambat pendistribusian dana anggaran ke berbagai program; perkiraan pendapatan dan proyeksi anggaran negara tidak disiapkan dalam suatu kerangka makro; tidak ada suatu kerangka penyatuan anggaran (unified framework for budgeting) mengingat anggaran rutin dan pembangunan disiapkan secara terpisah; sistem penganggaran yang berlaku menimbulkan kurangnya informasi mengenai hasil suatu program (program results); pelaksanaan anggaran dan monitoring masih menjadi hal yang lemah; dan susunan alokasi anggaran yang cukup terinci, secara tidak langsung mencerminkan kontrol yang kuat, namun dalam realisasinya ditengarai menimbulkan berbagai penyimpangan $(\mathrm{KKN})$ dan kebocoran anggaran.

Adapun pokok-pokok reformasi penganggaran yang terpenting meliputi penerapan pendekatan penganggaran dengan perspektif jangka menengah, memadukan (unifying) atau mengintegrasikan anggaran rutin dan anggaran pembangunan, dan penerapan anggaran berbasis kinerja.

Sebelum diberlakukannya UU No. 17/2003, belanja negara dibedakan atas pengeluaran rutin dan pengeluaran pembangunan (dual-budgeting). Pengeluaran rutin didefinisikan sebagai pengeluaran untuk keperluan operasional untuk menjalankan kegiatan rutin pemerintahan. Pengeluaran rutin mencakup belanja pegawai, belanja barang, pembayaran bunga, subsidi, dan belanja lain-lain. Sementara pengeluaran pembangunan didefinisikan sebagai pengeluaran yang menghasilkan nilai

${ }^{29}$ Undang-undang RI Nomor 17 Tahun 2003 tentang keuangan negara tambah aset, baik fisik maupun non fisik, yang dilaksanakan dalam periode tertentu. ${ }^{30}$

Adapun belanja pembangunan adalah pengeluaran berkaitan dengan proyek-proyek yang meliputi belanja modal dan belanja penunjang. Belanja modal mencakup pembebasan tanah, pengadaan mesin dan peralatan, konstruksi bangunan dan jaringan (infrastruktur), dan belanja modal fisik maupun non fisik lainnya. Sementara itu, belanja penunjang yang dialokasikan untuk mendukung pelaksanaan proyek terdiri dari gaji/upah, bahan, perjalanan dinas, dan belanja penunjang lainnya.

Pemisahan anggaran rutin dan anggaran pembangunan tersebut semula dimaksudkan untuk menekankan arti pentingnya pembangunan, namun dalam pelaksanaannya telah menunjukan banyak kelemahan. Pertama, duplikasi antara belanja rutin dan belanja pembangunan oleh karena kurang tegasnya pemisahan antara kegiatan operasional organisasi dan proyek, khususnya proyek-proyek non-fisik. Dengan demikian, kinerja sulit diukur karena alokasi dana yang ada tidak mencerminkan kondisi yang sesungguhnya. Kedua, penggunaan "dual budgeting" mendorong dualisme dalam penyusunan daftar perkiraan mata anggaran keluaran (MAK) karena untuk satu jenis belanja, ada MAK yang diciptakan untuk belanja rutin dan ada MAK lain yang ditetapkan untuk belanja pembangunan. Ketiga, analisis belanja dan biaya program sulit dilakukan karena anggaran belanja rutin tidak dibatasi pada pengeluaran untuk operasional dan belanja anggaran pembangunan tidak dibatasi pada pengeluaran untuk investasi. Keempat, proyek yang menerima anggaran pembangunan diperlakukan sama dengan satuan kerja, yaitu sebagai entitas akuntansi, walaupun proyek hanya bersifat sementara. Jika proyek sudah selesai atau dihentikan tidak ada kesinambungan dalam pertanggungjawaban terhadap asset dan kewajiban yang dimiliki proyek tersebut. Hal

30 Lihat Anggito Abimanyu, "Format Anggaran Terpadu Menghilangkan Tumpang Tindih", Kompas, Mei 2004. 
ini selain menimbulkan ketidakefisienan dalam pembiayaan kegiatan pemerintahan, juga menyebabkan ketidakjelasan keterkaitan antara output/outcome yang dicapai dengan penganggaran organisasi.

Selanjutnya, sebagaimana diamanatkan oleh UU No.17 Tahun 2003, maka sistem penganggaran mengacu pada praktek-praktek yang berlaku secara internasional. Menurut GFS (Government Financial Statistics) Manual 2001, sistem penganggaran belanja negara secara implisit menggunakan sistem unified budget, dimana tidak ada pemisahan antara pengeluaran rutin dan pembangunan, sehingga klasifikasi menurut ekonomi akan berbeda dari klasifikasi sebelumnya. Dalam hal ini, belanja negara menurut klasifikasi ekonomi dikelompokkan ke dalam (1) kompensasi untuk pegawai; (2) penggunaan barang dan jasa; (3) kompensasi dari modal tetap berkaitan dengan biaya produksi yang dilaksanakan sendiri oleh unit organisasi pemerintah; (4) bunga hutang; (5) subsidi; (6) hibah; (7) tunjangan sosial (social benefits); dan (8) pengeluaran-pengeluaran lain dalam rangka transfer dalam bentuk uang atau barang, dan pembelian barang dan jasa dari pihak ketiga untuk dikirim kepada unit lainnya.

Dalam melaksanakan perubahan format dan struktur belanja negara telah dilakukan dengan melakukan penyesuaianpenyesuaian, namun tetap mengacu GFS Manual 2001 dan UU No. 17 Tahun 2003. Beberapa catatan penting berkaitan dengan perubahan dan penyesuaian format dan struktur belanja negara yang baru antara lain:

Pertama, dalam format dan struktur I-account yang baru, belanja negara tetap dipisahkan antara belanja pemerintah pusat dan belanja untuk daerah, karena pos belanja untuk daerah yang berlaku selama ini tidak dapat diklasifikasikan ke dalam salah satu pos belanja negara sebagaimana diatur dalam UU No.17 Tahun 2003; Kedua, semua pengeluaran negara yang sifatnya bantuan/subsidi dalam format dan struktur baru diklasifikasikan sebagai subsidi; dan Ketiga, semua pengeluaran negara yang selama ini 'mengandung' nama lain-lain yang tersebar di hampir semua pos belanja negara, dalam format dan struktur baru diklasifikasikan sebagai belanja lain-lain.

Dengan berbagai perubahan dan penyesuaian tersebut, belanja negara menurut klasifikasi ekonomi (jenis belanja) terdiri dari (i) belanja pegawai, (ii) belanja barang, (iii) belanja modal, (iv) pembayaran bunga utang, (v) subsidi, (vi) hibah, (vii) bantuan sosial, dan (viii) belanja lain-lain. Sedangkan belanja untuk daerah, sebagaimana yang berlaku selama ini terdiri dari (i) dana perimbangan, dan (ii) dana otonomi khusus dan penyesuaian. Dengan adanya perubahan format dan struktur belanja negara menurut jenis belanja maka secara otomatis tidak ada lagi pemisahan antara belanja rutin dan belanja pembangunan (unified budget).

\section{Sistem APBN dengan Anggaran Berbasis Kenerja}

Sejalan dengan amanat UU No.17/2003, akan pula diterapkan secara penuh anggaran berbasis kinerja (performance-based budgeting) di sektor publik, agar penggunakan anggaran tersebut bisa dinilai kemanfaatan dan kegunaannya bagi masyarakat. Sebagaimana dipahami, selama ini kita menerapkan traditional budgeting atau dikenal pula sebagai line-item budgeting.Line-item budgeting ini mempunyai sejumlah karakteristik penting, antara lain tujuan utamanya adalah untuk melakukan kontrol keuangan, sangat berorientasi pada input organisasi, penetapannya melalui pendekatan incremental (kenaikan bertahap), dan tidak jarang dalam prakteknya memakai "kemampuan menghabiskan atau menyerap anggaran" sebagai salah satu indikator penting untuk mengukur keberhasilan organisasi.

Dalam praktek pelaksanaannya, karakteristik seperti di atas mengandung banyak kelemahan. Dalam rezim pemerintahan yang sarat dengan $\mathrm{KKN}$, karakteristik yang berkaitan dengan tujuan untuk melakukan kontrol keuangan, 
seringkali dilaksanakan hanya sebatas aspek administratifnya saja. Hal ini mungkin untuk dilakukan karena ditunjang oleh karakteristik lainnya yaitu sangat berorientasi pada input organisasi. Dengan demikian sistem anggaran tidak memberikan informasi tentang kinerja, sehingga sangat sulit untuk melakukan kontrol kinerja.

Kelemahan lainnya terkait dengan karakteristik penetapan anggaran dengan pendekatan incremental, yaitu menetapkan rencana anggaran dengan cara menaikkan jumlah tertentu pada jumlah anggaran yang lalu atau sedang berjalan. Melalui pendekatan ini, analisis yang mendalam tentang tingkat keberhasilan setiap program tidak dilakukan. Akibatnya adalah tidak tersedia informasi yang logis dan rasional tentang rencana alokasi anggaran tahun yang akan datang. Siapa atau unit mana mendapat berapa sering kali didasarkan pada catatan historis semata dan tidak berorientasi pada tujuan organisasi.

Kelemahan lainnya terkait dengan penggunaan "kemampuan menghabiskan anggaran" sebagai indikator keberhasilan. Apa yang sering terjadi dalam prakteknya adalah perilaku birokrat yang selalu berusaha untuk menghabiskan anggaran tanpa terkait dengan hasil dan kualitasnya. Tentu keadaan ini semakin buruk jika dikaitkan dengan karakter birokrat yang menurut Niskanen cenderung bersifat budget maximizer. ${ }^{31}$

Sebagai akibat dari berbagai kelemahan di atas, maka masalah besar yang dihadapi oleh sistem line-item budgeting adalah effectiveness problem, efficiency problem, and accountability problem. Bahkan jikapun sistemnya sudah transparan, maka informasi yang dapat diterima oleh masyarakat tidak terlalu penting, karena hanya berkaitan dengan input organisasi.

Sebagai respons terhadap permasalahan sistem anggaran line-item di atas, UU No. 17/2003 mengintrodusir sistem anggaran berbasis kinerja (performance

31 Baca Roy V. Salomo, “Anggaran yang Berorientasi pada Kinerja dan Kepemerintahan yang Baik", Jurnal Forum Inovasi, Vol. 5, DesemberFebruari 2003, 34-39 based budgeting). Anggaran berbasis kinerja adalah sistem penganggaran yang berorientasi pada output organisasi dan berkaitan sangat erat terhadap visi, misi, dan rencana strategi organisasi. Anggaran kinerja mengalokasikan sumberdaya pada program bukan pada unit organisasi semata dan memakai output measurement sebagai indicator kinerja organisasi. Lebih jauh ia mengkaitkan biaya dengan output organisasi sebagai bagian yang integral dalam berkas anggarannya.

Tujuan dari penetapan output measurement yang dikaitkan dengan biaya adalah untuk dapat mengukur tingkat efisiensi dan efektifitas. Hal ini sekaligus merupakan alat untuk dapat menjalankan prinsip akuntabilitas, karena yang diterima oleh masyarakat pada akhirnya adalah output dari suatu proses kegiatan birokrasi.

Ukuran-ukuran kinerja pada sistem anggaran yang berorientasi pada kinerja berguna pula bagi lembaga perwakilan rakyat (DPR/DPRD) pada saat menjalankan fungsi pembentukan kebijakan, fungsi penetapan anggaran, dan fungsi pelaksanaan pengawasan. Bagi manajemen puncak di pihak eksekutif berguna untuk melakukan kontrol manajemen dan kontrol kualitas serta dapat digunakan untuk sistem insentif pegawai. Dan pada akhirnya bagi masyarakat dapat memberikan kejelasan tentang kinerja dan akuntabilitas pemerintah. ${ }^{32}$

\section{Teori Peran Negara tentang APBN}

Teori peran negara akan digunakan untuk menganalisis pengelolaan anggaran yang ditujukan untuk kesejahteraan rakyat. Sebab, menurut Mardiasmo, anggaran merupakan pernyataan mengenai estimasi kinerja yang hendak dicapai selama periode waktu tertentu yang dinyatakan dalam ukuran finansial. Sedangkan penganggaran atau proses penyusunan anggaran adalah proses pengoperasional rencana dalam bentuk pengkualifikasian, biasanya dalam

${ }^{32}$ Lihat Roy V. Salomo, "Anggaran yang Berorientasi Pada Kinerja dan Kepemerintahan yang Baik", Jurnal Forum Inovasi, Vol. 5, DesemberFebruari 2003, 34-39. 
bentuk unit moneter, untuk kurun waktu tertentu. Jadi, penganggaran adalah proses atau metoda untuk mempersiapkan suatu anggaran.

Menurut Anthony dan Govindarajan, proses penyusunan anggaran pada dasarnya memiliki 4 tujuan utama yaitu: (1) menyelaraskan dengan rencana strategik, (2) untuk mengkoordinasikan kegiatan dari beberapa bagian dalam organisasi, (3) untuk memberikan tanggungjawab kepada manajer atau pimpinan, guna mengotorisasi jumlah dana yang dapat digunakan, dan untuk memberitahukan hasil yang mereka capai, serta (4) untuk mencapai kerjasama.

Karena demikian, pemerintah yang berkewajiban mengelola anggaran bila dilihat dari peran dan fungsi ekonomi menjadi perdebatan di kalangan ekonom sosialis dan kapitalis. Secara umum, peran dan fungsi pemerintah tersebut terkait dengan adanya upaya pencapaian tujuan pembangunan ekonomi berupa tingkat kesejahteraan masyarakat yang optimal. ${ }^{33}$ Namun demikian, perlu tidaknya turut campur pemerintah dalam mencapai tujuan tersebut diperdebatkan oleh sosialisme dan kapitalisme.

Kapitalisme yang memiliki semangat liberal dalam bentuk yang murni menganggap pemerintah tidak perlu ikut campur dalam perekonomian kecuali terkait dengan aturan-aturan yang tidak ditentukan oleh setiap individu pelaku ekonomi. Dalam hal ini, setiap orang memiliki kebebasan secara mutlak untuk mengatur dirinya sendiri, termasuk dalam aspek ekonomi.

Para ekonom klasik yang dimotori Adam Smith ${ }^{34}$ menilai bahwa pemerintah memiliki tiga fungsi, yaitu bidang pertahanan dan keamanan, keadilan sosial (tertib hukum), dan pekerjaan umum (sosial).

33 Lihat karya David Osborne and Ted Gaebler, Reinventing Government: How The Entrepreneurial Spirit is Transforming The Public Sector (Addison - Wesly Publishing Company, Inc., 1992).

${ }^{34}$ Baca lebih lanjut karya Adam Smith, The Wealth of Nations (London: J.M. Dens and Sons, 1977).
Aliran ini menganggap bahwa hal penting bagi pemerintah adalah tidak melakukan aktivitas yang dikerjakan oleh para individu, melainkan pemerintah hanya melakukan kegiatan ekonomi yang sama sekali tidak pernah dilakukan oleh individu atau sektor swasta baik secara perorangan maupun bersama-sama.

John Stuart Mill ${ }^{35}$ memberikan analisis bahwa konsep di atas dapat dianalisis melalui keberadaan perusahaan. Perusahaan lebih baik dijalankan oleh sektor swasta yang memang sudah tertarik untuk mengusahakannya dan membiarkan usahausaha tersebut tanpa ada campur tangan pemerintah, hanya saja memang ada beberapa pengecualiannya.

Sedangkan sistem ekonomi sosialis tidak menghendaki adanya kebebasan individu, sehingga kegiatan perekonomian harus dikuasai pemerintah sebagai institusi atau lembaga yang mewakili para individu. ${ }^{36}$ Peran pemerintah dalam mengatur perekonomian tersebut untuk mengatur perencanaan dan penggunaan faktor-faktor produksi, melaksanakan kegiatan produksi, dan mengatur distribusi barang-barang konsumsi, mengatur pendidikan serta kesehatan, dan lain sebagainya. ${ }^{37}$

Teori peran ekonomi pemerintah ini lebih lanjut akan digunakan untuk menganalisis pengelolaan APBN dari perencanaan, pelaksanaan, dan pertanggungjawabannya, sekaligus keterkaitan dengan adanya penyimpanganpenyimpangan di bidang anggaran. Secara umum, politik anggaran pemerintah ini tidak

${ }^{35}$ John Stuart Mill, Principles of Political Economy (London: Longman's Green and Co., 1921), Buku V, Bab II.

${ }^{36}$ Diskusi terbaru tentang sistem ekonomi sosialis yang mengalami transisi paradigma menuju ekonomi pasar dapat dibaca Shinichi Ichimura, et. al (eds.), Transition from Socialist to Market Economies: Comparison of European and Asian Experience (New York; Palgrave Macmillan, 2009), khususnya pada bagian III "The Role of the State and Market in Transition", 145-227.

${ }^{37}$ Lihat Shinichi Ichimura, et. al (eds.), Transition from Socialist to Market Economies: Comparison of European and Asian Experience (New York; Palgrave Macmillan, 2009), 151-153. 
dapat dilepaskan dari pengaruh globalisasi di bidang ekonomi, termasuk pasar bebas. Pengelolaan anggaran yang tidak transparan dan akuntabilitas oleh pemerintah akan menyebabkan kondisi ekonomi semakin terpuruk dan tertinggal negara lain. Karena itu, APBN yang dikelola pemerintah dalam menjalankan pembangunan seharusnya dapat meningkatkan pertumbuhan ekonomi, sekaligus berperan dalam mengokohkan nilai-nilai dan budaya bangsa Indonesia. Bukan sebaliknya, adanya alasan ekonomi menjadikan rakyat semakin terpinggirkan, dan masyarakat Indonesia menjadi "tamu" di rumah sendiri.

\section{Pengelolaan APBN Menuju Good Governance}

Dalam rangka akuntabilitas penataan keuangan negara, penyusunan keuangan negara mengacu pada norma-norma dan prinsip-prinsip sebagai berikut: pertama, transparansi dan akuntabilitas keuangan negara. Transparansi tentang keuangan negara merupakan salah satu persyaratan untuk mewujudkan pemerintahan yang baik, bersih dan bertanggungjawab. Mengingat penanganan pemerintah merupakan salah satu sarana evaluasi pencapaian kinerja dan tanggungjawab pemerintah mensejahterakan masyarakat, maka keuangan negara harus dapat memberikan informasi yang jelas tentang tujuan, sasaran, hasil dan manfaat yang diperoleh masyarakat dari suatu kegiatan atau proyek yang dianggarkan. Selain itu setiap dana yang diperoleh, penggunaannya harus dapat dipertanggungjawabkan. ${ }^{38}$

Kedua, disiplin keuangan negara. Keuangan negara yang disusun harus dilakukan berlandaskan azas efisiensi, tepat guna, tepat waktu dan dapat

${ }^{38}$ Abdul Hakim, Reformasi Penglolaan dan Pertanggungjawaban Keuangan Daerah (Yogyakarta: Fakultas Ekonomi UGM, 2006), 20-25. Lihat pula Bappenas, Public Good Governance: Sebuah Paparan Singkat (Jakarta: Sekretariat Pengembangan Public Good Governance, 2002), dan Bintoro Tjokroamidjojo, Pengantar Administrasi Pembangunan (Jakarta: PT Pustaka LP3ES Indonesia, 1995). dipertanggungjawabkan. Pemilihan antara belanja yang bersifat rutin degan belanja yang bersifat pembangunan/modal harus diklasifikasikan secara jelas, agar tidak terjadi percampuradukan kedua sifat anggaran yang dapat menimbulkan pemborosan dan kebocoran dana. Pendapatan yang direncanakan merupakan perkiraan yang terukur secara rasional yang dapat dicari untuk setiap sumber pendapatan, sedangkan belanja yang dianggarkan pada setiap pos/pasal merupakan batas tertinggi pengeluaran belanja. ${ }^{39}$

Ketiga, keadilan keuangan negara. Pembiayaan pemerintah dapat dilakukan melalui mekanisme pajak dan retribusi yang dipikul oleh segenap lapisan masyarakat, untuk itu pemerintah wajib mengalokasikan penggunaannya secara adil agar dapat dinikmati oleh seluruh kelompok masyarakat tanpa diskriminasi dalam pemberian pelayanan.

Keempat, efisiensi dan efektivitas keuangan negara. Dana yang tersedia harus dimanfaatkan dengan sebaik mugkin untuk dapat menghasilkan peningkatan pelayanan dan kesejahteraan yang maksimal guna kepentingan masyarakat. Oleh karena itu, untuk dapat mengendalikan tingkat efisiensi dan efektivitas anggaran, maka dalam perencanaan perlu ditetapkan secara jelas tujuan, sasaran, hasil dan manfaat yang akan diperoleh masyarakat dari suatu kegiatan atau proyek yang diprogramkan. ${ }^{40}$

Kelima, format keuangan negara. Pada dasarnya keuangan negara disusun berdasarakan format anggaran deficit (deficit budget format). Selisih antara pendapatan dan belanja mengakibatkan terjadinya surplus atau deficit anggaran. Apabila terjadi surplus, negara dapat membentuk dana cadangan, sedangkan bila terjadi deficit, dapat ditutupi melalui sumber pembiayaan pinjaman dan atau penerbitan obligasi negara

\footnotetext{
39 Abdul Hakim, Reformasi Penglolaan dan Pertanggungjawaban Keuangan Daerah, 34-50.

${ }^{40}$ Abdul Hakim, Reformasi Pengelolaan, 4578.
} 
sesuai dengan ketentuan perundangundangan yang berlaku. ${ }^{41}$

Keuangan negara yang disusun dengan pendekatan kinerja memuat hal-hal sebagai berikut: sasaran yang diharapkan menurut fungsi belanja, standar pelayanan yang diharapkan dan perkiraan biaya satuan komponen kegiatan yang bersangkutan, dan bagian pendapatan keuangan negara yang membiayai administrasi umum, belanja operasi dan pemeliharaan, dan belanja modal/pembangunan.

Untuk mengukur kinerja keuangan pemerintah tersebut, maka dikembangkan standar analisis belanja, tolok ukur kinerja dan standar biaya. Standar analisis belanja adalah penilaian kewajaran atas beban kerja dan biaya terhadap suatu kegiatan, dan yang dimaksud dengan tolok ukur kinerja adalah ukuran keberhasilan yang dicapai pada setiap unit organisasi perangkat pemerintah sedangkan yang dimaksud dengan standar biaya adalah harga satuan unit biaya yang berlaku bagi masing-masing daerah.

Sebagai ilustrasi, menurut alMawardi, ${ }^{42}$ pendapatan pemerintah yang ada pada kas negara disimpan dalam pos-pos terpisah (administrasi sistemik) dan dibelanjakan berdasarkan kebutuhannya masing-masing. Jika pos kategori tertentu tidak mencukupi untuk memenuhi pembelanjaan yang ditencanakan oleh kategori tersebut, penguasa dapat meminjam anggaran belanja dari pos lain. Sistem administrasi keuangan awal adalah apa yang sekarang dikenal dengan federalisme keuangan. Operasi keuangan dilakukan, secara umum, oleh unit keuangan lokal di cabang-cabang provinsinya. Pendapatan dari masing-masing provinsi digunakan untuk memenuhi pembiayaan provinsi tersebut. Jika pembiayaan lokal tersebut lebih kecil dari pendapatan lokal, gubernur mengirim sisanya ke keuangan pusat. Di sisi lain, jika pembiayaan melampaui pendapatan, kelebihan dari provinsi lain atau keuangan

\footnotetext{
${ }^{41}$ Bappenas, Public Good Governance, 56-

58.

42 Al-Mawardi, Al-Ahkam al-Sulthaniyah,
}

pusat dialihkan untuk memenuhi kekurangan tersebut. $^{43}$

Dengan demikian, sistem pendistribusian harta yang menjadi tanggung jawab lembaga keuangan negara dikelola berdasarkan kondisi keuangan yang ada dan wewenang lembaga ini dalam mendistribusikannya sesuai dengan tujuan masing-masing. Bagi al-Mawardi, ${ }^{44}$ tanggungjawab institusi keuangan atas penerimaan negara harus didistribusikan untuk kepentingan masyarakat. Dalam pandangan al-Mawardi, ${ }^{45}$ harta yang menjadi hak institusi keuangan diklasifikasikan menjadi dua bagian, yaitu harta yang hanya disimpan dalam perbendaharaan kas negara untuk tujuan tertentu, dan harta yang menjadi aset keuangan pemerintah yang diperoleh dari berbagai sumber penerimaan negara.

Adapun prinsip pengeluaran negara yang harus dipertimbangkan meliputi akuntabilitas dan value of money, kejujuran dalam penataan keuangan negara, transparansi dan pengendalian.

1. Akuntabilitas.

Akuntabilitas pengeluaran negara adalah kewajiban pemerintah untuk memberikan pertanggungjawaban, menyajikan dan melaporkan segala aktivitas dan kegiatan yang terkait dengan menggunakan uang publik, kepada pihak yang memiliki hak dan kewenangan untuk meminta pertanggung-jawaban tersebut (DPR dan masyarakat luas). Aspek penting yang harus dipertimbangkan oleh para manajer pemerintah adalah: a) Aspek legalitas pengeluaran negara yaitu setiap transaksi pengeluaran yang dilakukan harus dapat dilacak otoritas legalnya; b) Pengelolaan (stewardship) atas pengeluaran negara yang baik, perlindungan aset fisik dan finansial, mencegah terjadinya pemborosan dan salah urus.

Adapun prinsip-prinsip akuntabilitas pengeluaran negara adalah: (1) Adanya

\footnotetext{
${ }^{43}$ Al-Mawardi, Al-Ahkam al-Sulthaniyah, 3.

44 Al-Mawardi, Al-Ahkam al-Sulthaniyah,
}

213.

214 
sistem akuntansi dan sistem kemampuan negara yang dapat menjamin bahwa pengeluaran negara dilakukan secara konsisten sesuai dengan peraturan perundang-undangan yang berlaku; (2) Pengeluaran negara dapat menunjukan tingkat pencapaian tujuan dan sasaran yang telah ditetapkan; dan (3) Pengeluaran negara yang dilakukan dapat berorientasi pada pencapaian visi, misi, hasil dan manfaat yang akan diperoleh. ${ }^{46}$

\section{Value for Money}

Pengeluaran negara harus berdasarkan konsep value of money, seperti ditegaskan McKinney, yaitu: ${ }^{47}$ pertama, ekonomi, adalah hubungan antara pasar (nilai uang) dan masukan (input). Ekonomi adalah praktek pembelian barang dan jasa pada kualitas yang diinginkan dan pada harga terbaik yang memungkinkan. Sesuatu kegiatan operasional dikatakan ekonomis bila dapat menghilangkan atau mengurangi biaya yang dianggap tidak perlu. Oleh karena itu pada hakekatnya ada pengertian yang serupa antara efisiensi dengan ekonomi, karena kedua-duanya menghendaki penghapusan/penurunan biaya; kedua, efisiensi, berhubungan erat dengan konsep efektivitas, yaitu rasio yang membandingkan antara output yang dihasilkan terhadap input yang digunakan. Proses kegiatan operasional dapat dikatakan dilakukan secara efisien apabila suatu target kinerja tertentu (outcome) dapat dicapai dengan menggunakan sumber daya dan biaya yang serendah-rendahnya; dan ketiga, efektivitas, merupakan kaitan atau hubungan antara keluaran suatu pusat pertanggungjawaban dengan tujuan atau sasaran yang harus dicapainya. Efektivitas dalam pemerintahan

46 David Osborne and Ted Gaebler, Reinventing Government: How The intrepreneurial Spirit is Transforming The Public Sector (AddisonWesly Publishing Company, Inc., 1992), 78-90.

47 Jerome B. McKinney, Effective Financial Management in Public and Non Profit

Agencie.A Pratical and Intergrated Approach (Connecticut: Greenwood Press, Inc., 1986). Baca pula Richard A. Musgrave \& Peggy B. Musgrave, Public Finance in Theory and Practice (Singapore: Mc Graw-Hill, Inc., 1989). dapat diartikan penyelesaiannya kegiatan tepat pada waktunya dan di dalam batas anggaran yang tersedia, dapat berarti pula mencapai tujuan dan sasaran seperti apa yang telah direncanakan.

Aspek lain yang penting dari pengelolaan keuangan negara berupa pertanggungjawaban. Pertanggungjawaban merupakan ujung dari siklus anggaran setelah perencanaan dan pelaksanaan. Katakata kunci dalam pertanggungjawaban dalam evaluasi, evaluasi kinerja, dan akuntabilitas. Evaluasi kinerja kebijakan pada hakikatnya dilakukan untuk mengetahui ketepatan dan efektivitas baik kebijakan itu sendiri maupun sistem dan proses pelaksanaannya, agar dapat dilakukan langkah-langkah tindak lanjut untuk menghindarkan "biaya" (kemungkinan kemubaziran) yang lebih besar atau untuk mencapai "manfaat" yang lebih baik. ${ }^{48}$ Essensi evaluasi kinerja adalah perbandingan yang menyangkut kinerja dan tingkat efektivitas baik kebijakan maupun sistem dan proses pelaksanaan yang berkembang dalam mengatasi permasalahan yang dihadapi atau dalam mencapai tujuan yang ditetapkan.

Evaluasi kinerja yang dilakukan dalam rangka pemantauan pada pokoknya adalah menyediakan informasi bagi para pengelola kebijakan dan pembuat kebijakan mengenai ketepatan dan efektivitas kebijakan dan sistem serta proses pelaksanaannya, agar dapat dilakukan tindak lanjut dini apabila secara aktual ternyata ada hal-hal yang perlu dikoreksi baik pada kebijakan atau pun pada sistem dan proses pelaksanaannya.

Langkah dan tujuan serupa juga dilakukan dalam rangka pengawasan internal, karena sebenarnya pemantauan merupakan bagian dari kegiatan pengendalian internal yang diperlukan untuk peningkatan efektivitas manajemen, peningkatan efisiensi pemanfaatan sumbersumber, dan perbaikan-perbaikan lainnya ke depan yang dapat meliputi kebijakan dan sistem serta proses pelaksanaannya, dengan

48 Aan Jaelani, Keuangan Publik Islam: Refleksi APBN dan Politik Anggaran di Indonesia (Cirebon: Nurjati Press, 2014), 78-79. 
kemungkinan terminasi atau pun ekstensi dan modifikasi kebijakan yang dilaksanakan.

Evaluasi kinerja pada pengawasan eksternal, dilakukan dengan tujuan memberikan gambaran obyektif mengenai ketepatan dan efektivitas kebijakan ataupun sistem serta proses pelaksanaannya, kondisi biaya dan manfaat aktual dari kebijakan, perkembangan berbagai unsur dan indikator kinerja yang dicapai, yang diperlukan sebagai "pertanggungjawaban" atau pun "pertanggunggugatan" (responsibility and or accountability) suatu organisasi dalam melaksanakan tugas kelembagaannya. Hal terakhir itu menunjukkan maksud (motif) dilakukannya evaluasi kinerja, yang tentu dipengaruhi pula oleh posisi dan peran lembaga pengawasan eksternal yang melakukan evaluasi tersebut.

Eksplorasi atas pemikiran alMawardi, ${ }^{49}$ terkait dengan pengelolaan keuangan negara dapat dijelaskan bahwa seluruh jenis kekayaan yang menjadi milik masyarakat secara umum dan tidak menjadi milik masyarakat tertentu menjadi bagian dari aset keuangan pemerintah. Dengan demikian, pendapatan yang diperoleh secara sah oleh pemerintah dalam bentuk apapun harus tetap diperuntukkan untuk kebutuhan publik, kerena dianggap sebagai aset keuangan pemerintah.

Al-Mawardi ${ }^{50}$ mengklasifikasi lebih jauh tanggung jawab negara dalam pengelolaan anggaran ke dalam dua kategori. Kategori pertama, yang harus dibiayai negara, meliputi tanggungjawab yang disediakan karena nilai-nilai yang diterimanya, yaitu dipergunakan untuk penggajian para tentara, harga persenjataan dan kompensasi. Karena tanggungjawab ini berlawanan dengan nilai yang diterima, negara harus menetapkan tuntutan tersebut. Pelaksanaan tanggungjawab tersebut menimbulkan biaya yang harus disediakan oleh negara.

\footnotetext{
49 Al-Mawardi, Al-Ahkam al-Sulthaniyah,

214.

50 Al-Mawardi, Al-Ahkam al-Sulthaniyah,
}

Kategori kedua, meliputi tanggungjawab yang telah ditetapkan melalui bantuan dan kepentingan umum. ${ }^{51}$ AlMawardi berpendapat, pelaksanaan jenis tanggungjawab ini berkaitan dengan keberadaan dana dalam kas negara. Jika ada dana yang memadai di baitul mal, tanggungjawab kepentingan umum harus dipenuhi. Namun, jika tidak ada dana, tanggungjawab tersebut menjadi tanggung jawab sosialbagi semua masyarakat. ${ }^{52}$ Dengan demikian, jika tanggung jawab ini diabaikan akan mempengaruhi seluruh masyarakat, tanggung jawab keuangan berubah menjadi tanggung jawab seluruh masyarakat. Al-Mawardi ${ }^{53}$ berpendapat, ketika tidak ada dana, beban tanggungjawab tersebut menjadi kewajiban seluruh masyarakat. Dengan kata lain, sistem distribusi keuangan pada APBN yang bersumber dari berbagai jenis penerimaan didasarkan atas terpenuhinya kebutuhan dasar masyarakat, atau pengeluaran pemerintah dilakukan dalam rangka menciptakan kesejahteraan masyarakat (almashlahah al-'ammah). ${ }^{54}$

Ada reformasi atau paradigma baru dalam keuangan negara, yaitu paradigma yang menuntut besarnya akuntabilitas dan transparansi dari penataan keuangan negara dengan memperhatikan asas keadilan dan kepatutan, dengan ciri-ciri sebagai berikut: ${ }^{55}$ pertama, dari vertical accountability menjadi horizontal accountability. Jika selama ini

51 Baca Aan Jaelani, Sejarah Pemikiran Ekonomi Islam: Kontribusi Sarjana Muslim dalam Pemikiran dan Analisis Ekonomi (Cirebon: CV. Aksarasatu, 2018).

52 Aan Jaelani, Manajemen Zakat di Indonesia dan Brunei Darussalam (Cirebon: Nurjati Press, 2015), 45.

53 Al-Mawardi, Al-Ahkam al-Sulthaniyah, 214-215.

54 Aan Jaelani, Slamet Firdaus \& Juju Jumena, Renewable Energy Policy in Indonesia: The Qur'anic Scientific Signals in Islamic Economics Perspective. International Journal of Energy Economics and Policy, 2017: 7 (4), 193-204.

55 Roy V. Salomo, "Anggaran yang Berorientasi pada Kinerja dan Kepemerintahan yang Baik", Jurnal Forum Inovasi, Vol. 5, DesemberFebruari 2003, 34-39. 
pertanggungjawaban atas penataan keuangan negara lebih ditujukan pada pemerintah yang lebih tinggi (Provinsi atau Pusat), maka dengan reformasi saat ini pertanggungjawaban lebih ditujukan kepada rakyat (DPR). Laporan pertanggungjawaban keuangan negara disampaikan kepada DPR secara periodik, tidak lagi sekedar laporan tentang APBN tetapi mencakup pula laporan aliran kas dan neraca.

Kedua, dari traditional budget menjadi performance budget. Selama ini penataan keuangan negara adalah dengan sistem tradisional. Sistem tradisional, sistem penyusunannya adalah dengan pendekatan incremental dan "line item" dengan penekanan pada pertanggungjawaban pada setiap input yang dialokasikan. Melalui reformasi, anggaran harus disusun dengan pendekatan atau sistem anggaran kinerja (performance budgeting), dengan penekanan pertanggunganjawaban tidak sekedar pada input tetapi juga pada output dan outcome.

Ketiga, dari pengendalian dan audit keuangan ke pengendalian dan audit keuangan, dan kinerja. Sebelum reformasi terdapat pengendalian dan audit keuangan negara, bahkan juga audit kinerja. Namun, oleh karena sistem anggaran yang tidak memasukan kinerja, maka proses audit kinerja menjadi tidak berjalan dengan baik. Dalam reformasi ini, oleh karena sistem penganggaran yang mengunakan sistem penganggaran kinerja (performance budgeting) maka pelaksanaan pengendalian dan audit keuangan negara dan audit kinerja akan menjadi lebih baik.

Keempat, lebih menerapkan konsep value for money. Reformasi penataan keuangan negara saat ini menghendaki penerapan konsep value for money atau yang lebih dikenal degan konsep 3 E (ekonomi, efisien, dan efektif). Oleh karena itu dalam reformasi ini pemerintah diminta baik dalam mencari dana maupun menggunakan dana selalu menerapkan prinsip $3 \mathrm{E}$ tersebut. Hal ini mendorong pemerintah berusaha selalu memperhatikan tiap sen/rupiah dan (uang) yang diperoleh dan digunakan. Perhatian tertuju pada hubungan antara input-outputoutcome.

Kelima, penerapan pusat pertanggungjawaban. Dalam reformasi penataan keuangan negara ini konsep pusat pertanggungjawaban (responsibility center) diterapkan. Penerapan ini akan memudahkan pengukuran kinerja setiap unit organisasi. Pada konsep ini unit organisasi dapat diperlakukan sebagai pusat pertanggungjawaban pendapatan (revenue) seperti dinas pendapatan, biaya (expense) seperti bagian keuangan. "laba" (profit), dan investasi seperti BUMD atau Perusahaan Daerah.

Keenam, perubahan sistem akuntansi keuangan pemerintahan. Untuk mendukung perubahan-perubahan yang telah dikemukakan di atas direformasi pula sistem akuntansi di pemerintahan. Jika selama ini pemerintah menggunakan sistem pencatatan tunggal (single entry system) maka dirubah menjadi sistem ganda (double entry system). Selain itu, selama ini digunakan pencatatan atas dasar kas (cash-basis) maka dirubah menjadi atas dasar aktual medication (modified accrual basis). Selain itu, perubahan dalam akuntansi dan pengelolaan negara, yang pada gilirannya menuntut adanya neraca laporan negara, tidak lagi sekedar laporan perhitungan keuangan negara.

Karena itu rencana pembangunan yang telah disusun oleh pemerintah bersama DPR/DPRD dan anggarannya berupa APBN/APBD, semestinya dilaksanakan dengan baik sesuai amanat rakyat. Sebab dalam pembelanjaan publik, menurut pandangan al-Mawardi, setiap penurunan dalam kekayaan publik adalah peningkatan kekayaan negara dan setiap penurunan dalam kekayaan negara adalah peningkatan dalam kekayaan publik. ${ }^{56}$ Hal ini berarti bahwa dalam APBN, prioritas utama diperuntukkan bagi kepentingan masyarakat, semakin banyak anggaran pemerintah yang digunakan

56 Al-Mawardi, Al-Ahkam al-Sulthaniyah, 176. 
untuk rakyat akan menunjukkan peningkatan hasil-hasil pembangunan.

Konsep ini menunjukkan pula, seperti ditegaskan al-Mawardi bahwa negara dalam pengelolaan harta harus berdasarkan syari'ah dengan memperhatikan prinsip-prinsip kemaslahatan umum. Sebagai catatan, harta yang bersumber dari masyarakat dikumpulkan melalui institusi pemerintah kemudian didistribusikan kepada mereka yang berhak menerimanya.

Dalam hal ini, al-Mawardi cukup teliti dalam hal pendistribusian harta oleh petugas negara dan para penerimanya yang disertai dengan bukti penerimaan. Hal ini dalam rangka menghindari kesalahan distribusi harta kepada mereka yang tidak berhak dan mencegah terjadinya perselisihan dengan mereka yang berhak menerima, namun tidak menerima sebagaimana mestinya.

\section{Penutup}

Sistem anggaran berbasis kinerja berorientasi pada output pemerintah yang mengalokasikan sumber daya pada program bukan pada unit organisasi semata dan memakai pengukuran pengeluaran sebagai indikator kinerja pemerinrah. Sistem ini mengkaitkan biaya dengan output tersebut sebagai bagian yang integral dalam berkas anggarannya. Tujuan dari penetapan output measurement yang dikaitkan dengan biaya adalah untuk dapat mengukur tingkat efisiensi dan efektifitas. Hal ini sekaligus merupakan alat untuk dapat menjalankan prinsip akuntabilitas, karena yang diterima oleh masyarakat pada akhirnya adalah output dari suatu proses kegiatan birokrasi.

\section{Daftar Pustaka}

Abu Yusuf. Kitab al-Kharaj. Beirut: Dar alMa'arif, 1979.

Adam, Rainer, et al. Persaingan dan Ekonomi Pasar di Indonesia. Jakarta: Friedrich Nauman StiftungIndonesia, 2006.
Ahmad, Khurshid (ed.). Studies in Islamic Economics. Jeddah: King Abdul Aziz University, 1980.

Ahmad, Mustaq. Business Ethics in Islam. Pakistan: International Institute of Islamic Thought, 2001.

Al-Assal, A. Muhammad.dan Fathi Abd. Karim. Hukum Ekonomi Islam. Jakarta: Pustaka Firdaus, 1999.

Al-Ghazali. Ihya' 'Ulum al-Din. Beirut: Dar al-Fikr, 1998.

Al-Mawardi, Abu Hasan Ali. Adab al-Dunya wa al-Din. Beirut: Dar al-Fikr, 1995.

Al-Mawardi, Abu Hasan Ali. al-Ahkam alSulthaniyah wa Wilayat al-Diniyah. Beirut: Dar al-Fikr, 1996.

Al-Shatibi, Abu Ishaq. al-Muwafaqat $f i$ Ushul al-Syari'ah. Cairo: alMaktabah al-Tijanyah al-Kubra, 1975.

Azmi, Sabahuddin. Islamic Economics: Public Finance in Early Islamic Thought . New Delhi: Goodword Books, 2002.

Boadway, Robin W. dan Neil Bruce. Welfare Economics. Oxford: Basil Blackwell, 1984.

Essid, Yassine. A Critique of The Origins of Islamic Economic Thought. Leiden: E.J. Brill, 1995.

George, Susan. Republik Pasar Bebas. Jakarta: INFID/Bina Rena Pariwara, 2002.

Hamdani, Ikhwan. Sistem Pasar. Jakarta: Nurinsani, 2003.

Ibn Khaldun. Al-Muqaddimah Ibn Khaldun. Cairo: Dar Ibn al-Haitham, 2005/1426.

Ibn Taymiyah. Al-Hisbah fi al-Islam. Beirut: Dar al-Kutub al-'Arabiyah, 1994.

Ibn Taymiyah. al-Siyasah al-Shar'iyah $f i$ Islah al-Ra'iy waal-Ra'iyah. Saudi Arabia: Dar 'alam al-Fawa'id, 2001.

Ichimura, Shinichi, et al. (eds.). Transition from Socialist to Market Economies: Comparison of European and Asian Experience. New York; Palgrave Macmillan, 2009. 
Islahi, Abdul Azim. Economic Concepts of Ibnu Taimiyah. United Kingdom: The Islamic Foundation, 1996.

Ismawan, Indra. Sukses di Era Ekonomi Liberal Bagi Koperasi dan Perusahaan Kecil-Menengah, Jakarta: Gramedia, 2001.

Jaelani, Aan, Firdaus, Slamet dan Jumena, Juju. Renewable Energy Policy in Indonesia: The Qur'anic Scientific Signals in Islamic Economics Perspective. International Journal of Energy Economics and Policy, 2017: 7 (4), 193-204.

Jaelani, Aan. Fiscal Policy in Indonesia: Analysis of State Budget 2017 in Islamic Economic Perspective. International Journal of Economics and Financial Issues, 2017: 7 (5): 14-24.

Jaelani, Aan. Keuangan Publik Islam: Refleksi APBN dan Politik Anggaran di Indonesia. Cirebon: Nurjati Press, 2014.

Jaelani, Aan. Keuangan Publik: Analisis Sejarah Pemikiran Ekonomi Islam. Cirebon: CV. Aksarasatu, 2018.

Jaelani, Aan. Manajemen Zakat di Indonesia dan Brunei Darussalam. Cirebon: Nurjati Press, 2015.

Jaelani, Aan. Masyarakat Islam dalam Pandangan al-Mawardi. Bandung: Pustaka Setia, 2006.

Jaelani, Aan. Sejarah Pemikiran Ekonomi Islam: Kontribusi Sarjana Muslim dalam Pemikiran dan Analisis Ekonomi. Cirebon: CV. Aksarasatu, 2018.

Mishra, Ramesh. Globalization and the Welfare State. London: McMillan, 2000.

Mubyarto. Membangun Sistem Ekonomi. Yogyakarta: BPFE-Yogyakarta, 2000.

Mubyarto. Reformasi Sistem Ekonomi Dari Kapitalisme Menuju Ekonomi Kerakyatan, Yogyakarta: Aditya Media, 1999.
Naqvi, Haider. Ethics and Economics: an Islamic Synthesis. London: The Islamic Foundation, 1981.

Roncaglia, Alessandro. The Wealth of Ideas: a History of Economic Thought. New York: Cambridge University Press, 2006.

Rostows, W. The Stages of Economic Growth, a Non-Communist Manifesto. Cambridge: Cambridge University Press, 1967.

Rothbard, Murray N. Power and Market Government and the Economy, Kansas: Institute for Humane Studies, Inc., 1977.

Salomo, Roy V. "Anggaran yang Berorientasi pada Kinerja dan Kepemerintahan yang Baik", Jurnal Forum Inovasi, Vol. 5, DesemberFebruari 2003, 34-39.

Samuelson, Paul A. Economics, New York: McGraw-Hill Book Company, 2008.

Schumpeter, J.A. Capitalism, Socialism and Democracy. New York: Harper \& Row, 1950.

Siddiqui, M.N. Role of the State in the Economy:-An Islamic Perspective. The Islamic Foundation, UK., 1996.

Smith, Adam. An Inquiry into the Nature and Causes of The Wealth of Nations. (New Rochelle, N.Y : Arlington House, 1966.

Suharto, Edi. Membangun Masyarakat Memberdayakan Rakyat: Kajian Strategis Pembangunan Kesejahteraan Sosial dan Pekerjaan Sosial.Bandung: Refika Aditama, 2005.

Swasono, Sri Edi. Judicial Review Testimoni Sri-Edi Swasono terhadap UU No. 38 Tahun 2008 tentang ASEAN Charter, Mahkamah Konstitusi RI, 22 Juli 2011

Swasono, Sri-Edi. "Pancasila, Humanisme, Pasal 33 UUD 1945, Kooperativisme, Menolak Liberalisme", Orasi Ilmiah, Universitas Pasundan Bandung, 19 Juli 2011.

Swasono, Sri-Edi. Ekspose Ekonomika: Mewaspadai Globalisasi dan Pasar 
Bebas, Yogyakarta: Pustep UGM, Todaro, Michael P. dan Stephen C. Smith. 2010.

Swasono, Sri-Edi. Kebersamaan dan Asas Kekeluargaan: Mutualism and Britherhood, Jakarta: UNJ Press, 2005.

Swasono, Sri-Edi. Mewaspadai Pasar Bebas (dalam Dari Lengser ke Lengser), Jakarta: Penerbit Universitas Indonesia, 2001.

Pembangunan Ekonomi di Dunia Ketiga . Jakarta: Erlangga, 2003.

Umar Chapra, M. The Future of Economics: An Islamic Perspective. Leicester: The Islamic Foundation, 2000.

Wallerstein, I. The Capitalist WorldEconomy. New York: Cambridge University Press, 1979.

Warde, Ibrahim. Islamic Finance in the Global Economy. Edinburgh: Edinburgh University Press, 2000. Ekonomi dan Kebangkitan Ekonomi Kerakyatan, Jakarta: Pustaka Quantum, 2002. 